\title{
Polyamines and other accessory sex gland secretions in human seminal plasma 8 years after vasectomy
}

\author{
H. Jakobsen, H. Rui*, Y. Thomassen†, T. Hald and K. Purvis* \\ Department of Urology, Herlev Hospital, University of Copenhagen, DK-2730 Herlev, Denmark; \\ and ${ }^{*}$ Institute of Pathology and $\dagger$ Institute of Occupational Health, Rikshospitalet, Oslo-1, Norway
}

\begin{abstract}
Summary. In 56 males, vasectomized 8 years previously, and in 56 age-matched nonvasectomized controls, a number of secretory products of prostatic, seminal vesicular and epididymal/testicular origin were used to monitor post-operative changes in accessory sex gland function.

Significant reductions were observed in seminal plasma volume $(3.0 \mathrm{vs} 4.9 \mathrm{ml}$, $P<0.01)$, and the total ejaculate contents of zinc $(5.1 v s 9.7 \mu \mathrm{mol}, P<0.01)$, magnesium (10.6 vs 26.5 $\mu \mathrm{mol}, P<0.01$ ), PAP (371 vs $1260 \mathrm{IU}, P<0.005$ ) and citric acid (76.7 vs $127.9 \mu \mathrm{mol}, P<0.05)$, indicating a major impact on secretions of prostatic origin. Unaltered PGE-1 (54.3 vs 53.2 $\mu \mathrm{g}, P>0.95)$ and fructose $(3.9 v s 4.5 \mu \mathrm{mol}$, $P>0 \cdot 1)$ indicated no effects on the secretory function of the seminal vesicles.

A marked reduction was demonstrated in the ejaculatory contents of the polyamines, spermidine (366 vs $650 \mathrm{nmol}, P<0.005)$ and spermine $(5435$ vs $11804 \mathrm{nmol}$, $P<0.05)$ but not their acknowledged precursor, putrescine, which is also of prostatic origin.
\end{abstract}

Keywords: prostate; prostatic secretions; vasectomy; polyamines; man

\section{Introduction}

Vasectomy in rats and monkeys causes biochemical changes in the prostate gland (Kinson \& Bruce, 1977; Srivastava et al., 1986), an effect which is believed to result from a break in the vascular continuity between the gland and the vas deferens (Pierrepoint, 1975). In spite of these published observations, there is a paucity of studies on the effects of vasectomy on accessory sex gland function in the human male. Furthermore, a critical analysis of the world literature revealed that, in the majority of human studies, glandular function was monitored by examining the concentrations of secretory products in the ejaculate (Gregoire \& Moran, 1972, 1973; Kothari et al., 1977; Barkan et al., 1978; Nikkanen, 1978; Mendiratta et al., 1980; Naik et al., 1980; Bendvold et al., 1985; Parrish et al., 1987). Seminal plasma is a complex mixture of the products of several glands and it may therefore be more correct to compare glandular function on the basis of their total contributions to the ejaculate. In this way, the confounding effects of alterations in the volumes of secretion produced by the individual glands are avoided. Indeed, vasectomy has been shown to decrease the volume of the ejaculate to an extent which cannot be explained by the absence of the testicular/ epididymal contribution (Jouannet \& David, 1978; Naik et al., 1980; Nag Das et al., 1984).

The purpose of the present cross-sectional study was to investigate the long-term effects of vasectomy on accessory sex gland function in a carefully controlled study, using the total ejaculate contents of secretory products as indicators of changes in secretory function. The study involved the analysis of many glandular characteristics including putrescine and the polyamines, prostatic products which are also acknowledged to be associated with growth processes in general (Pegg, 1970; Russell, 1970; Chiu \& Sung, 1972; Konecki et al., 1975). 


\section{Materials and Methods}

Study groups. Fifty-six men were investigated at a median of 8 years and 4 months after vasectomy (range 8 years 2 months-9 years 1 month). A control group of equal size was selected with the assistance of the National Population Registry. Every control man was non-vasectomized, married, lived in the same geographic area and was father to at least one child. It was the aim of the study that all control men were born on the same day and year as the corresponding patient. When this condition could not be fulfilled, a person born on a day as close to the patient's birthday as possible was selected. All control men and patients gave their informed consent.

Operation. Vasectomy had been carried out on an out-patient basis under local analgesia with resection of $1-2 \mathrm{~cm}$ of the vas deferens via small bilateral scrotal incisions. The resected part of the vas deferens was examined by freezemicroscopy within $30 \mathrm{~min}$ after resection and later by light-microscopy of a haematoxylin/eosin stained, formalinfixed preparation. Azoospermia was confirmed by sperm analysis 2 and 3 months after operation.

Medical history. A careful history of present and previous diseases, medication, and alcohol and tobacco consumption was obtained. Special attention was paid to genito-urinary disorders. The height and weight of each person was measured. Information on sexual activity (frequency of coitus and masturbation) was obtained.

Investigations. A semen sample was provided by each individual at home by masturbation into a condom (PLAN, Danmarks Apotekerforening, Denmark). The condoms contained no chemical addition. The semen samples were all collected after at least $48 \mathrm{~h}$ sexual abstinence. Immediately after ejaculation the semen was frozen at $-20^{\circ} \mathrm{C}$ and 3 days later transported frozen to the laboratory where it was transferred to $-80^{\circ} \mathrm{C}$.

Analysis of semen samples. The samples were thawed. Samples from control men were centrifuged at $1500 \mathrm{~g}$ for $10 \mathrm{~min}$ at $+4^{\circ} \mathrm{C}$ and the spermatozoa were removed. Seminal plasma volume was measured by weighing on an electronic balance ( 2 decimal places).

The methods used for the determination of prostatic acid phosphatase (PAP; EC 3.1.3.2), citric acid and fructose have been described previously (Rui et al., 1984), with intra-assay coefficients of variation of $6 \cdot 3 \%, 14 \cdot 3 \%$ and $10 \cdot 8 \%$, respectively. For the determination of zinc and magnesium a Perkin-Elmer model 5000 atomic absorption spectrometer and a microcup flame atomization technique was used. In the assay, $25 \mu \mathrm{l}$ samples were deproteinized with $10 \%$ trichloroacetic acid. Protein was assessed by the method of Lowry et al. (1951). Prostaglandin E was determined using a radioimmunoassay kit (Travenol Laboratories Inc., Baxter World Trade Corp., Deerfield, IL, USA: cat. no. CA-501). Testosterone was assessed using a radioimmunoassay procedure described elsewhere (Purvis et al., 1974). Maltase was measured according to Gunaga et al. (1967), using $25 \mu \mathrm{l}$ seminal plasma, a final maltose concentration of $35 \mathrm{~mm}$, and an incubation time of $3 \mathrm{~h}$ at $37^{\circ} \mathrm{C}$.

Putrescine, spermidine and spermine were determined by a high-pressure liquid-chromatography system (Laboratory Data Control, Riviera Beach, FL, USA) using a procedure essentially like that of Seiler \& Knödgen (1978). Briefly, $20-\mu$ l samples were mixed with $180 \mu \mathrm{l}$ 1,6-diaminohexane (internal standard; $20 \mathrm{nmol}$ dissolved in water) and deproteinized with $200 \mu \mathrm{l} 0.4 \mathrm{M}$-perchloric acid on ice for $20 \mathrm{~min}$, followed by centrifugation at $2000 \mathrm{~g}$ for $30 \mathrm{~min}$. A sample $(25 \mu \mathrm{l})$ of the supernatant was diluted with $175 \mu \mathrm{l}$ water and mixed with $100 \mathrm{mg} \mathrm{NaHCO}$ and $0.4 \mathrm{ml}$ dansyl chloride $(0.011 \mathrm{M}$ in acetone). The reaction mixture was allowed to stand overnight in the dark at room temperature. Excess dansyl chloride was removed by addition of $0.1 \mathrm{ml} \mathrm{L}$-proline $(1.3 \mathrm{M}$ in water) followed by a further $30 \mathrm{~min}$ of incubation in the dark. The contents of the tubes then were dried at $65^{\circ} \mathrm{C}$ under a stream of air, dissolved in $0.1 \mathrm{ml}$ water, and extracted with $0.5 \mathrm{ml}$ toluene. A sample $(300 \mu \mathrm{l})$ of the toluene phase was evaporated to dryness and dissolved in a final volume of $600 \mu \mathrm{l}$ methanol. Then $20 \mu \mathrm{l}$ were applied to the column $(250 \times 4.6 \mathrm{~mm}$ i.d, Supelcosil LC-18, particle size $5 \mu \mathrm{m}$; Supelco SA, Gland, Switzerland) by an autosampler, and the separation of the dansyl derivatives was obtained using a linear methanol/water gradient changing from $65 \%$ to $100 \%$ methanol (Ratburn Chemicals Ltd, Walkerburn, UK: h.p.l.c. grade) in $23 \mathrm{~min}$ at a flow rate of $1 \mathrm{ml} / \mathrm{min}$. A fluorescence detector with an excitation filter of $340 \mathrm{~nm}$ and an emission filter of $460 \mathrm{~nm}$ was used, and standards containing $100 \mathrm{pmol}$ spermine, $50 \mathrm{pmol}$ of 1,6 -diaminehexane, $10 \mathrm{pmol}$ spermidine, and $10 \mathrm{pmol}$ putrescine per 20 - $\mu$ injection volume were run after every 7 th sample.

Prolactin was measured by a radioimmunoassay using ${ }^{125}$ I-labelled human prolactin and a second antibody solidphase technique (Immunobead Reagent, cat. no. 170-5604, Bio-Rad, Richmond, CA, USA). Prolactin values were expressed in international units (50 IU corresponds to $1 \mathrm{mg}$ prolactin, WHO 75/504).

Statistical analysis. Non-parametric methods were chosen due to the abnormal distribution of the data. The Mann-Whitney rank sum test was used for comparison of differences between the two groups.

\section{Results}

The median age of men in both groups was 46 years (range 35-70 years). Information on health status revealed no statistically significant difference between the two groups with respect to general health, hospitalization, medication, alcohol and tobacco consumption, height, weight and surface area. 
The 2 groups were comparable with respect to sexual activity and duration of abstinence before semen sampling; the median number of ejaculations per month was 8 in both groups (vasectomy group range: $1-30$, control group range: $0-60), P>0 \cdot 1$. The mean abstinence period in the vasectomy group was 3.9 days (range $2-8$ days) whilst it was 4.7 days (range $2-10$ days) in the control group $(P>0.05)$.

Results of the semen analysis are summarized in Table 1. The data are expressed both as concentrations and as total ejaculate contents. In 4 cases ( 3 controls, 1 vasectomized), the ejaculates were not adequately liquefied after incubation and had to be excluded from the analyses. In other cases, the ejaculate volume was not sufficient to carry out all of the analyses. In these cases the assay of prostatic products was given priority. However, these uneven numbers did not affect the age distribution in the various analyses (Table 2).

Table 1. Accessory sex gland products (concentration and total amount) in seminal plasma from vasectomized men and age-matched control men

\begin{tabular}{|c|c|c|c|c|}
\hline Variable & Units & $\begin{array}{l}\text { Vasectomized } \\
\text { men }\end{array}$ & $\begin{array}{c}\text { Control } \\
\text { men }\end{array}$ & $P$ \\
\hline Ejaculate vol. & $\mathrm{ml}$ & $\begin{array}{l}3 \cdot 0(0 \cdot 5-9 \cdot 6) \\
(55)\end{array}$ & $\begin{array}{l}4.9(0.74-16.3) \\
(53)\end{array}$ & $<0.01$ \\
\hline Zinc & $\begin{array}{l}\mathrm{mM} \\
\mu \mathrm{mol}\end{array}$ & $\begin{array}{l}1 \cdot 76(0 \cdot 21-5 \cdot 75) \\
5 \cdot 10(1 \cdot 11-31 \cdot 85) \\
(41)\end{array}$ & $\begin{array}{l}2.27(0.21-5.99) \\
9.69(0.73-38.04) \\
(49)\end{array}$ & $\begin{array}{l}>0.05 \\
<0.01\end{array}$ \\
\hline Magnesium & $\begin{array}{l}\mathrm{mM} \\
\mu \mathrm{mol}\end{array}$ & $\begin{array}{l}4.82(0 \cdot 29-12 \cdot 06) \\
10 \cdot 60(0 \cdot 71-67.63) \\
(41)\end{array}$ & $\begin{array}{l}6 \cdot 17(1 \cdot 61-17 \cdot 7) \\
26 \cdot 46(3 \cdot 49-102 \cdot 69) \\
(49)\end{array}$ & $\begin{array}{l}<0.05 \\
<0.01\end{array}$ \\
\hline PAP & $\begin{array}{l}\mathrm{IU} / \mathrm{ml} \\
\mathrm{IU}\end{array}$ & $\begin{array}{l}143(8 \cdot 7-1277) \\
371(55-7930) \\
(41)\end{array}$ & $\begin{array}{l}298(35-1653) \\
1260(112-10496) \\
(51)\end{array}$ & $\begin{array}{l}<0.01 \\
<0.005\end{array}$ \\
\hline Citric acid & $\begin{array}{l}\mathrm{mM} \\
\mu \mathrm{mol}\end{array}$ & $\begin{array}{l}26 \cdot 0(4-145) \\
76 \cdot 7(5 \cdot 4-360 \cdot 8) \\
(42)\end{array}$ & $\begin{array}{l}28.8(4-115) \\
127.9(14-523.9) \\
(52)\end{array}$ & $\begin{array}{l}>0.5 \\
<0.05\end{array}$ \\
\hline Putrescine & $\begin{array}{l}\mu \mathrm{M} \\
\mathrm{nmol}\end{array}$ & $\begin{array}{l}71(0-962) \\
202 \cdot 5(0-4540) \\
(43)\end{array}$ & $\begin{array}{l}42 \cdot 15(0-1262) \\
153 \cdot 7(0-4573) \\
(48)\end{array}$ & $\begin{array}{l}>0.8 \\
>0.6\end{array}$ \\
\hline Spermidine & $\begin{array}{l}\mu \mathrm{M} \\
\mathrm{nmol}\end{array}$ & $\begin{array}{l}111(32-1393) \\
366(49 \cdot 5-8650) \\
(43)\end{array}$ & $\begin{array}{l}136(45-570) \\
650(91 \cdot 8-2806 \cdot 9) \\
(51)\end{array}$ & $\begin{array}{l}>0.2 \\
<0.005\end{array}$ \\
\hline Spermine & $\begin{array}{l}\mu \mathrm{M} \\
\mathrm{nmol}\end{array}$ & $\begin{array}{l}1760(276-4932) \\
5435(386-36252) \\
(43)\end{array}$ & $\begin{array}{l}2566(244-13676) \\
11804(610-69747) \\
(51)\end{array}$ & $\begin{array}{l}>0.2 \\
<0.05\end{array}$ \\
\hline Fructose & $\begin{array}{l}\mathrm{mM} \\
\mu \mathrm{mol}\end{array}$ & $\begin{array}{l}11(4 \cdot 4-27 \cdot 5) \\
38 \cdot 8(4 \cdot 8-208 \cdot 2) \\
(40)\end{array}$ & $\begin{array}{l}12 \cdot 2(1 \cdot 0-36 \cdot 6) \\
44 \cdot 7(3 \cdot 5-270 \cdot 8) \\
(51)\end{array}$ & $\begin{array}{l}>0.90 \\
>0.2\end{array}$ \\
\hline PGE-1 & $\begin{array}{l}\mu \mathrm{g} / \mathrm{ml} \\
\mu \mathrm{g}\end{array}$ & $\begin{array}{l}25 \cdot 5(1 \cdot 6-110) \\
54 \cdot 3(1 \cdot 7-354) \\
(28)\end{array}$ & $\begin{array}{l}18 \cdot 0(1 \cdot 0-84) \\
53 \cdot 2(3 \cdot 1-400) \\
(31)\end{array}$ & $\begin{array}{l}>0.1 \\
>0.95\end{array}$ \\
\hline Maltase & $\begin{array}{l}\text { units } / \mathrm{ml} \\
\text { units }\end{array}$ & $\begin{array}{l}0.54(0.10-20.20) \\
1.42(0.36-92.92) \\
(26)\end{array}$ & $\begin{array}{l}3.48(0.63-9.03) \\
11 \cdot 87(2 \cdot 75-40.63) \\
(28)\end{array}$ & $\begin{array}{l}<0.0001 \\
<0.0001\end{array}$ \\
\hline Protein & $\begin{array}{l}\mathrm{mg} / \mathrm{ml} \\
\mathrm{mg}\end{array}$ & $\begin{array}{l}57 \cdot 0(36 \cdot 0-87.4) \\
282.0(25 \cdot 5-835.4) \\
(23)\end{array}$ & $\begin{array}{l}55 \cdot 7(25 \cdot 6-91 \cdot 7) \\
305 \cdot 2(29 \cdot 6-937 \cdot 2) \\
(31)\end{array}$ & $\begin{array}{l}>0.5 \\
>0.6\end{array}$ \\
\hline Prolactin & $\begin{array}{l}\mathrm{mIU} / \mathrm{ml} \\
\mathrm{mIU}\end{array}$ & $\begin{array}{l}418(193-1030) \\
1010(313-6077) \\
(27)\end{array}$ & $\begin{array}{l}629(181-1730) \\
2128(489-4500) \\
(29)\end{array}$ & $\begin{array}{l}<0.05 \\
<0.001\end{array}$ \\
\hline Testosterone & $\begin{array}{l}\mathrm{ng} / \mathrm{ml} \\
\mathrm{ng}\end{array}$ & $\begin{array}{l}0.15(0.04-1.64) \\
0.45(0.11-2.46) \\
(41)\end{array}$ & $\begin{array}{l}0 \cdot 16(0.04-1.95) \\
0.69(0 \cdot 19-5.85) \\
(51)\end{array}$ & $\begin{array}{l}>0.6 \\
<0.005\end{array}$ \\
\hline
\end{tabular}

Values are median and range with no. of patients in parentheses. 
Table 2. Age (median and range) of vasectomized patients and control men subjected to the various analyses of seminal plasma

\begin{tabular}{lccccc}
\hline & \multicolumn{2}{c}{$\begin{array}{c}\text { Vasectomized } \\
\text { men }\end{array}$} & \multicolumn{2}{c}{$\begin{array}{c}\text { Control } \\
\text { men }\end{array}$} & $P$ \\
\hline Zinc and magnesium & 46 & $(35-70)$ & 46 & $(35-70)$ & $>0.95$ \\
PAP & 46 & $(35-70)$ & 45 & $(35-70)$ & $>0 \cdot 55$ \\
Citric acid & 46 & $(35-70)$ & $45 \cdot 5(35-70)$ & $>0 \cdot 60$ \\
Putrescine & 46 & $(35-70)$ & 45 & $(35-70)$ & $>0 \cdot 45$ \\
Spermidine and spermine & 46 & $(35-70)$ & 45 & $(35-70)$ & $>0 \cdot 55$ \\
Fructose & $46 \cdot 5(35-70)$ & 45 & $(35-70)$ & $>0 \cdot 45$ \\
PGE-1 & 46 & $(37-60)$ & 46 & $(35-60)$ & $>0 \cdot 80$ \\
Maltase & 45 & $(37-60)$ & 45 & $(35-60)$ & $>0 \cdot 95$ \\
Protein & 45 & $(35-70)$ & 45 & $(35-70)$ & $>0.60$ \\
Prolactin & 46 & $(37-60)$ & 45 & $(35-60)$ & $>0.90$ \\
Testosterone & 46 & $(35-70)$ & 45 & $(35-70)$ & $>0 \cdot 50$ \\
\hline
\end{tabular}

A significant reduction in the volume of seminal plasma was found in vasectomized subjects. When seminal concentrations were compared, a significant reduction in magnesium $(4.82 \mathrm{vs} 6.17 \mathrm{mM}$, $P<0.05)$, PAP (143 vs $298 \mathrm{IU} / \mathrm{ml}, P<0.01)$, maltase $(0.54$ vs $3.48 \mathrm{Units} / \mathrm{ml}, P<0.0001)$ and prolactin $(418$ vs $629 \mathrm{mIU} / \mathrm{ml}, P<0.02)$ could be detected. When the total ejaculate contents of the secretory products were compared, the majority of secretory products underwent a significant decrease, except for putrescine $(202.5 \mathrm{vs} 153.7 \mathrm{nmol}, P>0.6)$, fructose $(3.88 v s 4.47 \mu \mathrm{mol}$, $P>0.1$ ), PGE-1 (54.3 vs 53.2 $\mu \mathrm{g}, P>0.95)$ and protein (282.0 vs $305.2 \mathrm{mg}, P>0.6)$.

\section{Discussion}

The decrease in polyamine content of the ejaculate and the simultaneous reduction in zinc, magnesium, PAP and citrate indicate a major influence of vasectomy on the secretory function of the prostate 8 years after the operation.

The prostate in mammals is the richest source of putrescine, spermidine and spermine (Mann \& Lutwak-Mann, 1981). These aliphatic amines are involved in protein synthesis and have many direct actions on DNA- and RNA-polymerases, methylases, hydrolases and actions involving tRNA, rRNA and mRNA in almost all somatic cells (Pegg, 1970; Russell, 1970; Chiu \& Sung, 1972; Konecki et al., 1975). It is intriguing that putrescine, a precursor in the biosynthesis of the polyamines, is also not secreted in reduced quantities by the gland after vasectomy. On the other hand, previous studies indicate that, in a variety of physiological situations, the levels of this amine are not often correlated to changes in the other prostatic secretory products (Purvis et al., 1988). For example, frequent ejaculation causes a gradual increase in its secretion, in the presence of decreasing quantities of the other constituents. The paradoxical changes in putrescine may reflect a greater involvement in intracellular biochemical mechanisms other than those involved in secretion, for example, compensatory changes in protein and RNA synthesis.

Zinc, magnesium, PAP, citrate and the polyamines are all acknowledged products of the prostate gland and their seminal plasma concentrations are invariably correlated to each other (Rui et $a l ., 1986)$. These and other products are secreted by relatively unknown pathways and there is some evidence that they may be produced in different areas of the gland (Hoare et al., 1956; Gyorkey et al., 1967). However, the present study indicates effects of vasectomy on prostate secretory function involving the majority of secretory parameters. This reduces the possibility that the operation has an influence on discrete areas of the gland or on specific biosynthetic pathways. Such generalized effects on glandular function are generally more reminiscent of disturbances in a hormonal influence, for example a reduced effect of testosterone. Indeed, Pierrepoint (1975) postulated that vasectomy can theoretically interfere with the transport of high concentrations of androgens 
from the testis to the prostate via the deferential vein. Our own studies and those of others (Adamopoulos et al., 1976; Purvis et al., 1976; Lannon et al., 1980; Ying et al., 1983) suggest that the androgen content of the ejaculate is reduced after vasectomy, which may not just be explained by the absence of epididymal and testicular secretions.

The major reduction in seminal maltase in vasectomized men almost certainly reflects its epididymal origin (Chapdelaine et al., 1978). The same explanation is also relevant for the change in seminal prolactin concentrations, which is primarily derived from the testis/epididymis and also the seminal vesicles (Schoenfeld et al., 1979; Smith \& Luqman, 1982; Rui et al., 1985). Both observations confirm previous reports on the effects of vasectomy on maltase and prolactin in the ejaculate (Davis \& Lubell, 1975; Chapdelaine et al., 1978; Luqman et al., 1979; Luqman \& Smith, 1979; Naik et al., 1980; Smith \& Luqman, 1982).

PGE and fructose are primarily secretions of the seminal vesicles and the ampulla of the vas (Schoenfeld et al., 1979; Gerozissis et al., 1982; Sivanesaratnam, 1982; Bendvold et al., 1985). No changes could be detected in their seminal concentrations or their total ejaculate contents after the operation, indicating no major influence of vasectomy on this area of the reproductive tract. Other published reports on these glandular markers tend to be contradictory. Some studies have suggested an influence of the operation on fructose (Naik et al., 1976; Kothari et al., 1977; Nikkanen, 1978), and others no influence on fructose or PGE (Thakur et al., 1975; Srivastava, K. C., et al., 1981; Srivastava, A., et al., 1983; Bendvold et al., 1985). The increase in seminal fructose has been explained by some (Kothari et al., 1977) to reflect a reduced utilization of the sugar in the absence of spermatozoa. In these cases, comparisons were made on the basis of concentrations rather than the total quantity of fructose secreted.

The reduction in seminal plasma volume cannot be explained by the absence of the contribution from the vas deferens, which under normal conditions only accounts for $2-5 \%$ of the total ejaculate volume. The specific reduction in the quantities of prostatic materials in the ejaculate implies that the reduction in volume reflects a diminished contribution from this gland. Not only are the specific secretory products of the prostatic epithelium decreased but also the fluid vehicle in which they are secreted.

In conclusion, the results of the present study suggest that vasectomy causes disturbances in prostate secretory function, seen 8 years after the operation. This influence can be best demonstrated when glandular function is assessed using the total ejaculate contents of the secretory products rather than their concentrations. Differences in the expression of the data may explain divergent findings which have previously appeared in the literature. The mechanisms of this influence are at present unknown but may support previous suggestions that there may exist local mechanisms for the transport of high concentrations of androgens from the testis to the prostate (Skinner \& Rowson, 1968; Pierrepoint, 1975; Srivastava et al., 1986).

This study was supported by the Special Programme of Research, Development and Research Training in Human Reproduction, World Health Organization.

\section{References}

Adamopoulos, D.A., Lawrence, D.M. \& Swyer, G.I.M. (1976) Determination of testosterone concentration in semen of men with normal or subnormal sperm counts and after vasectomy. Acta eur. fertil. 7, 219-225.

Barkan, T., Paz, G., Homonnai, Z.T., Chayn, R. \& Kraicer, P.F. (1978) Spermine and citric acid in human prostatic fluid. Int. J. Androl. 1, 393-396.

Bendvold, E., Svanborg, K., Bygdeman, M. \& Noren, S. (1985) On the origin of prostaglandins in human seminal fluid. Int. J. Androl. 8, 37-43.

Chapdelaine, P., Tremblay, R.R., Dube, J.Y., St.-Yves, C.
\& Mailhot, J. (1978) Origin of maltase and variations in infertile men. Archs Androl. 1, 61-68.

Chiu, J.-F. \& Sung, S.C. (1972) Effect of spermidine on the activity of DNA polymerase. Biochem. Biophys. Acta 281, 535-542.

Davis, J.E. \& Lubell, I. (1975) Advances in understanding the effects of vasectomy. Mt Sinaii J. Med. N.Y. 42, 391-397.

Gerozissis, K., Jouannet, P., Soufir, J.C. \& Dray, F. (1982) Origin of prostaglandins in human semen. $J$. Reprod. Fert. 65, 401-404.

Downloaded from Bioscientifica.com at 04/26/2023 12:32:56AM via free access 
Gregoire, A.T. \& Moran, M.J. (1972) The lactic dehydrogenase, glucose phosphate isomerase, fructose, and protein content of pre- and postvasectomy necrospermic and azoospermic human seminal plasma. Fert. Steril. 23, 708-711.

Gregoire, A.T. \& Moran, M.J. (1973) The enzyme activity, protein and fructose content of normal, oligospermic, postvasectomy, and infertile azoospermic men. Fert. Steril. 24, 208-211.

Gunaga, K.P., Sheth, A.R. \& Rao, S.R. (1967) Maltase activities in the accessory reproductive organs of rats and mice. Ind. J. exp. Biol. 5, 141-143.

Gyorkey, F., Min, K.-W., Huff, J.A. \& Gyorkey, F. (1967) Zinc and magnesium in human prostate gland: normal, hyperplastic, and neoplastic. Cancer Res. 27, 1348-1353.

Hoare, R., Delory, G.E. \& Penner, D.W. (1956) Zinc and acid phosphatase in the human prostate. Cancer $\mathbf{9}$, $721-726$.

Jouannet, P. \& David, G. (1978) Evolution of the properties of semen immediately following vasectomy. Fert. Steril. 29, 435-441.

Kinson, G.A. \& Bruce, N. (1977) Responses to vasectomy performed at different ages in the rat. Res. Com. Chem. Path. Pharmacol. 18, 561-564.

Konecki, D., Kramer, G., Pinphanichakarn, P. \& Hardesty, B. (1975) Polyamines are necessary for maximum in vitro synthesis of globin peptides and play a role in chain initiation. Archs Biochem. Biophys. 169, 192-198.

Kothari, L.K., Gupta, A.S., Chaturvedi, K.C. \& Paliwal, O.L. (1977) Seminal fructose and acid phosphatase in vasectomized men. Int. J. Fertil. 22, $60-62$.

Lannon, D.L., Massart, C., Chambon, Y., Nicol, M. \& Allannic, H. (1980) Testosterone and 5a-dihydrotestosterone. Int. J. Androl. 3, 502-506.

Lowry, O.H., Rosebrough, N.J., Farr, A.L. \& Randall, R.J. (1951) Protein measurement with the folin phenol reagent. J. biol. Chem. 193, 265-275.

Luqman, W. \& Smith, L. (1979) Seminal immunoreactive prolactin before and after vasectomy. Clin. Endocrinol. 10, 213-215.

Luqman, W., Smith, M. \& Plymate, S. (1979) Inherent ranges of seminal prolactin in pre- and postvasectomy subjects. Int. J. Fertil. 24, 286-288.

Mann, T. \& Lutwak-Mann, C. (1981) Male Reproductive Function and Semen. Springer Verlag, New York.

Mendiratta, R., Dasgupta, P.R. \& Sheth, A.R. (1980) Vasectomy and biochemical composition of human seminal plasma. Ind. J. exp. Biol. 18, 409-410.

Nag Das, S.K., Bhattacharyya, A. \& Bhattacharyya, A.K. (1984) Aminopeptidase in human seminal plasma. Andrologia 16, 451-457.

Naik, V.K., Thakur, A.N., Sheth, A.R., Joshi, U.M., Rao, S.S., Pardanani, D.S., Kulsreshtha, J.K. \& Handa, R.K. (1976) The effect of vasectomy on pituitarygonadal function in men. J. Reprod. Fert. 48, 441-442.

Naik, V.K., Joshi, U.M. \& Sheth, A.R. (1980) Long-term effects of vasectomy on prostatic function in men. $J$. Reprod. Fert. 58, 289-293.

Nikkanen, V. (1978) Seminal fructose, citric acid and acid phosphatase before and after vasectomy in man. Andrologia 10, 464-466.

Parrish, R.F., Kessler, R., Shapiro, C.E. \& Fair, W.R. (1987) Vasectomy and vasovasostomy have no effect on seminal plasma zinc concentrations. J. Urol. 137, 228-229.

Pegg, A.E. (1970) Biosynthesis of putrescine and polyamines in mammalian tissues. Ann. N.Y. Acad. Sci. 171, 977-987.

Pierrepoint, C.G. (1975) Does hormone transfer along the vasa deferentia contribute to the control of prostatic function and could it be a factor in the etiology of prostatic hyperplasia? In Normal and Abnormal Growth of the Prostate, pp. 517-529. C. C. Thomas, Springfield.

Purvis, K., Illius, A.W. \& Haynes, N.B. (1974) Plasma testosterone concentration in the ram. J. Endocr. 61, 241-253.

Purvis, K., Saksena, S.K., Cekan, Z., Diczfalusy, E. \& Giner, J. (1976) Endocrine effects of vasectomy. Clin. Endocrin. 5, 263-272.

Purvis, K., Attramadal, A. \& Rui, H. (1988) Secretory function of the prostate gland. Scand. J. Urol. Nephrol., Suppl. 107, 46-51.

Rui, H., Gerhardt, P., Mevåg, B., Thomassen, Y. \& Purvis, K. (1984) Seminal plasma characteristics during frequent ejaculation. Int. J. Androl. 7, 119-128.

Rui, H., Torjesen, H.A., Jakobsen, H. \& Purvis, K. (1985) Testicular and glandular contributions to the prolactin pool in human semen. Archs Androl. 15, 129-136.

Rui, H., Thomassen, Y., Oldereid, N.B. \& Purvis, K. (1986) Accessory sex gland function in normal young (20-25 years) and middle-aged (50-55 years) men. J. Androl. 7, 93-99.

Russell, D.H. (1970) Discussion: Putrescine and spermidine biosynthesis in growth and development. Ann. N.Y. Acad. Sci. 171, 772-782.

Schoenfeld, C., Amelar, R.D., Dubin, L. \& Numeroff, M. (1979) Prolactin, fructose, and zinc levels found in human seminal plasma. Fert. Steril. 32, 206-208.

Seiler, N. \& Knödgen, B. (1978) Determination of di-and polyamines by high performance liquid chromatographic separation of their 5-di-methyl-aminonaphthalene-1-sulphonyl derivatives. $J$. Chromatogr. 145, 29-39.

Sivanesaratnam, V. (1982) Male infertility due to absence of vas deferens. Europ. J. Obstet. Gynec. Reprod. Biol. 14, 31-35.

Skinner, J.D. \& Rowson, L.E.A. (1968) Effects of testosterone injected unilaterally down the vas deferens on the accessory glands of the ram. J. Endocr. 42, 355-356.

Smith, M.L. \& Luqman, W.A. (1982) Prolactin in seminal fluid. Archs Androl. 9, 105-113.

Srivastava, A., Chopra, S.K. \& Dasgupta, P.R. (1983) Biochemical analysis of human seminal plasma $I$. Fructose, ascorbate, cholesterol, adenosine triphosphatase and lactic dehydrogenase. Andrologia 15, $431-435$.

Srivastava, A., Chowdhury, A.R. \& Setty, B.S. (1986) Testicular regulation and sub-cellular distribution of zinc in the epididymis and vas deferens of rhesus monkey (Macaca mulatta). Acta endocr., Copenh. $113,440-449$.

Srivastava, K.C., Bansal, R.K. \& Tiwari, K.P. (1981) Prostaglandin E and 19-hydroxy prostaglandin E content in the semen of men with normal sperm 
characteristics, men with abnormal sperm characteristics, vasectomised men and polyzoospermic men. Dan. med. Bull. 28, 201-203.

Thakur, P.V., Sheth, A.R., Ros, S.S. \& Thaker, P.V. (1975) Effect of vasectomy on the prostatic function as indicated by seminal maltase activity. Contraception 11, 155-159.
Ying, W., Hedman, M., de la Torre, B., Jensen, F., Pedersen, P.H. \& Diczfaluzy, E. (1983) Effect of vasectomy on the steroid profile of human seminal plasma. Int. J. Androl. 6, 116-124.

Received 20 September 1988 